\title{
Performa Puyuh yang Diberi Limbah Sawit Fermentasi dengan Pleurotus ostreatus dalam Ransum
}

\section{Performance of Quail Given Palm Oil Waste Fermented with Pleurotus ostreatus in Ration}

\author{
R. Gusri ${ }^{1 *}$, Nuraini ${ }^{2}$, dan Mirzah ${ }^{2}$ \\ ${ }^{1}$ Program Pascasarjana, Fakultas Peternakan, Universitas Andalas, Padang - Indonesia \\ ${ }^{2}$ Fakultas Peternakan, Universitas Andalas, Padang - Indonesia \\ *Corresponding E-mail: rahmat.gusri@gmail.com \\ (Diterima: 16 Maret 2020; Disetujui: 25 Mei 2020)
}

\begin{abstract}
ABSTRAK
Tujuan dari penelitian ini untuk mengetahui pengaruh dan batasan penggunaan limbah sawit yang difermentasi dengan Pleurotus ostreatus dalam ransum terhadap performa puyuh petelur. Penelitian ini menggunakan 200 ekor puyuh (Coturnix coturnix japonica) umur 20 minggu dengan produksi telur $60 \%$. Metode yang digunakan adalah eksperimen dengan Rancangan Acak Lengkap (RAL) dengan 5 perlakuan $(0 \%, 6 \%, 12 \%, 18 \%$, dan 24\% limbah sawit fermentasi dengan Pleurotus ostreatus) dengan 4 ulangan. Parameter yang diamati dalam penelitian ini adalah performa (konsumsi ransum, produksi telur harian, massa telur, dan konversi ransum). Hasil analisis keragaman menunjukkan bahwa penggunaan limbah sawit fermentasi dengan Pleurotus ostreatus tidak berpengaruh ( $\mathrm{P}>0,05)$ terhadap performa puyuh. Kesimpulan penelitian ini adalah campuran limbah sawit yang difermentasi dengan Pleurotus ostreatus sampai level $24 \%$, pada kondisi ini diperoleh konsumsi ransum $21,51 \mathrm{~g} / \mathrm{ekor} / \mathrm{hari}$, produksi telur harian $61,08 \%$, massa telur 6,44 g/ekor/hari, dan konversi ransum 3,34.
\end{abstract}

Kata kunci: limbah sawit, Pleurotus osteratus, performa puyuh, ransum

\section{ABSTRACT}

This study aims to determine the limits and effects of the use of palm oil waste, which is fermented with Pleurotus ostreatus in rations to the performance of laying quail. This study used 200 quails (Coturnixcoturnix japonica) aged 20 weeks, with $60 \%$ egg production. The method used was an experiment with a Completely Randomized Design (CRD) with five treatments $(0 \%, 6 \%, 12 \%, 18 \%$, and $24 \%$ fermented palm waste with Pleurotus ostreatus) with four replications. The observed parameters in this study are performance (feed consumption, egg production, egg mass, and feed conversion). The results analysis of variance showed that the use of fermented palm waste with Pleurotus ostreatus does not affect $(P>0.05)$ to the quail performance. The conclusion of this study is the palm waste fermented with Pleurotus ostreatus to the level of $24 \%$, in this condition ration consumption was $21.51 \mathrm{~g} /$ bird/day, daily egg production was $61.08 \%$, egg mass was $6.44 \mathrm{~g} / \mathrm{bird} /$ day, and feed conversion was 3.34 .

Keywords: palm waste, Pleurotus ostreatus, quail performance, ration

\section{PENDAHULUAN}

Puyuh merupakan salah satu unggas yang dewasa ini sudah banyak dikembangkan karena produksi telur yang tergolong cukup tinggi. Pemeliharaan puyuh tergolong mudah dipelihara, biaya untuk pemeliharaan tergolong rendah, dan pemakaian lahan yang tidak begitu luas. Tingginya produksi dari telur puyuh harus diimbangi ketersediaan pakan, kualitas pakan yang baik dan tidak bersaing dengan kebutuhan manusia. Salah satu langkah yang dapat dilakukan adalah memanfaatkan limbah agroindustri. Limbah agroindustri yang dapat dimanfaatkan adalah limbah industri perkebunan kelapa sawit. 
Luas perkebunan kelapa sawit menurut data dari Kementerian Pertanian Republik Indonesia (2018) luas lahan perkebunan sawit pada tahun 2017 sebesar $14.030 .573 \mathrm{Ha}$ dengan total produksi kelapa sawit sebesar 37.812.628 ton. Limbah industri perkebunan kelapa sawit yang dapat dimanfaatkan sebagai bahan pakan alternatif adalah lumpur sawit dan bungkil inti sawit. Setiap ton tandan buah sawit segar (TBS) dapat menghasilkan 294 $\mathrm{kg}$ lumpur sawit dan $35 \mathrm{~kg}$ bungkil inti sawit (Mathius, 2003).

Lumpur sawit merupakan limbah dari industri pembuatan minyak sawit tetapi memiliki kandungan protein kasar yang rendah yaitu $11,30 \%$ dan serat kasar yang tinggi yaitu $25,80 \%$ (lignin tinggi yaitu $19,19 \%$ dan selulosa tinggi yaitu 20,22\%), sehingga dilakukan pencampuran dengan bungkil inti sawit yang merupakan agro byproduct yang memiliki kandungan protein kasar yang lebih tinggi yaitu $16,30 \%$ dan serat kasar yang lebih rendah yaitu 21,75\% (lignin $16,96 \%$ dan selulosa $17,67 \%$ ) dibandingkan lumpur sawit (Nuraini et al., 2016). Limbah sawit ini dicampur dengan dedak untuk mendapatkan aerasi yang baik (porositas) untuk perkembangan mikroorganisme.

Campuran limbah sawit dan dedak mengandung protein kasar $13.35 \%$ tetapi memiliki kandungan serat kasar yang masih tinggi yaitu $22,61 \%$ (lignin $15.59 \%$ dan selulosa $17.59 \%$ ), maka perlu dilakukan upaya penurunan serat kasar salah satunya fermentasi menggunakan Pleurotus ostreatus. Pleurotus ostreatus merupakan jamur pelapuk putih yang mampu mendegradasi lignin karena memproduksi enzim ligninolitik seperti laccase, lignin peroxidase, dan mangan peroxidase (Periasamy and Natarajan, 2004), selain itu juga menghasilkan enzim protease (Shaba and Baba, 2012), selulase dan amilase (Sudiana dan Rahmansyah, 2002).

Penelitian terhadap campuran limbah sawit dan dedak fermentasi telah dilakukan dan didapatkan hasil dengan dosis $8 \%$ dan lama fermentasi 9 hari terjadinya kenaikan protein kasar dari 13,35\% menjadi 20,36\% serta penurunan serat kasar dari 22,61\% menjadi $14,74 \%$ (lignin 10,75\% dan selulosa $13,60 \%$ ) dan diperoleh kandungan lemak kasar 6,07\%, Ca 0,53\%, P 0,41\%, serta Energi Metabolis 2.469,85 kkal/kg (Hasil analisa Laboratorium Nutrisi Non Ruminansia dan Teknologi Industri Pakan, 2019). Meningkatnya kandungan protein kasar dan terjadinya penurunan kandungan serat kasar yang terkandung dari campuran limbah sawit dan dedak fermentasi dengan Pleurotus ostreatus diharapkan penggunaannya didalam ransum berpengaruh baik terhadap performa produksi puyuh petelur.

\section{METODE}

Penelitian ini menggunakan puyuh petelur sebanyak 200 ekor, umur 20 minggu dengan tingkat produksi $60 \%$, campuran limbah sawit dan dedak fermentasi dengan Pleurotus ostreatus (LSDF). Ransum disusun dengan iso protein $20 \%$ dan iso energi $2.800 \mathrm{kkal} / \mathrm{kg}$. Bahan pakan, komposisi ransum, dan kandungan zat makanan ransum penelitian dapat dilihat pada Tabel 1, 2, dan 3. Perlengkapan yang digunakan dalam penelitian kandang batrai sebanyak 20 petak dengan tempat pakan dan minum, timbangan digital, dan timbangan analitik

\section{Rancangan Percobaan}

Penelitian menggunakan metode eksperimen menggunakan rancangan acak lengkap dengan 5 perlakuan dan 4 ulangan. Setiap unit percobaan diisi masing-masing dengan 10 ekor puyuh. Masing- masing perlakuan dibedakan dengan pemberian level campuran limbah sawit dan dedak fermentasi dengan Pleurotus ostreatus yang berbeda didalam ransum. Setiap perlakuan diberikan tanda sebagai berikut:

$$
\begin{aligned}
& A=\text { Ransum dengan } 0 \% \mathrm{LSDF} \\
& \mathrm{B}=\text { Ransum dengan } 6 \% \mathrm{LSDF} \\
& \mathrm{C}=\text { Ransum dengan } 12 \% \mathrm{LSDF} \\
& \mathrm{D}=\text { Ransum dengan } 18 \% \mathrm{LSDF} \\
& \mathrm{E}=\text { Ransum dengan } 24 \% \mathrm{LSDF}
\end{aligned}
$$


Tabel 1. Bahan pakan, kandungan zat makanan (\%), dan energi metabolisme (kkal/kg) bahan penyusun ransum (as feed) ${ }^{\mathrm{a}}$

\begin{tabular}{lcccccccc}
\hline Bahan Pakan & $\begin{array}{c}\text { PK } \\
(\%)\end{array}$ & $\begin{array}{c}\text { LK } \\
(\%)\end{array}$ & $\begin{array}{c}\text { SK } \\
(\%)\end{array}$ & $\begin{array}{c}\mathrm{Ca} \\
(\%)\end{array}$ & $\begin{array}{c}\mathrm{P} \\
(\%)\end{array}$ & $\begin{array}{c}\text { ME } \\
(\text { Kkal })^{\mathrm{c}}\end{array}$ & $\begin{array}{c}\mathrm{Met}^{\mathrm{c}} \\
(\%)\end{array}$ & $\begin{array}{c}\mathrm{Lys}^{\mathrm{c}} \\
(\%)\end{array}$ \\
\hline Konsentrat $126^{\mathrm{b}}$ & 38,00 & 4,00 & 3,00 & 5,50 & 1,00 & $2.910,00$ & 1,000 & 1,760 \\
Jagung giling & $8,58^{\mathrm{a}}$ & 2,66 & 2,90 & 0,38 & 0,19 & $3.300,00$ & 0,000 & 0,300 \\
Dedak & 9,50 & 5,09 & 12,84 & 0,69 & 0,26 & $1.640,00$ & 0,270 & 0,670 \\
Minyak Kelapa & 0,00 & 100,00 & 0,00 & 0,00 & 0,00 & $8.600,00$ & 0,000 & 0,000 \\
LSDF & $20,36^{\mathrm{d}}$ & $6,07^{\mathrm{d}}$ & $14,74^{\mathrm{d}}$ & $0,53^{\mathrm{d}}$ & $0,41^{\mathrm{d}}$ & $2.469,85^{\mathrm{d}}$ & $0,630^{\mathrm{a}}$ & $1,070^{\mathrm{a}}$ \\
Bungkil Kedelai & 43,35 & 2,49 & 3,05 & 0,63 & 0,36 & $2.240,00$ & 0,500 & 0,600 \\
T. tulang & 0,00 & 0,00 & 0,00 & 24,00 & 12,00 & 0,00 & 0,000 & 0,000 \\
CaCO $_{3}$ & 0,00 & 0,00 & 0,00 & 40,00 & 0,00 & 0,00 & 0,000 & 0,000 \\
Top mix $^{\mathrm{e}}$ & 0,00 & 0,00 & 0,00 & 0,06 & 0,00 & 0,00 & 0,003 & 0,003 \\
\hline Kan $^{\mathrm{e}}$ & & & & & & & &
\end{tabular}

Keterangan: ${ }^{a}$ Nuraini et al. (2019)

${ }^{b}$ Label Kemasan Produk PT. Charoen Pokphan

'Scott et al. (1982)

${ }^{\mathrm{d} H a s i l ~ a n a l i s a ~ L a b o r a t o r i u m ~ N u t r i s i ~ N o n ~ R u m i n a n s i a ~ d a n ~ T e k n o l o g i ~ I n d u s t r i ~ P a k a n ~ F a k u l t a s ~}$ Peternakan Universitas Andalas (2019)

'Yuniza (2018)

Tabel 2. Komposisi ransum penelitian (\%)

\begin{tabular}{lrrrrr}
\hline Bahan Pakan & Ransum A & Ransum B & Ransum C & Ransum D & Ransum E \\
\hline Konsentrat 126 & 29,50 & 29,50 & 29,50 & 29,50 & 29,50 \\
Jagung giling & 47,50 & 45,00 & 43,00 & 41,75 & 38,50 \\
Dedak & 8,00 & 6,50 & 4,50 & 1,75 & 1,00 \\
Minyak Kelapa & 0,50 & 0,50 & 0,50 & 0,50 & 0,50 \\
LSDF & 0,00 & 6,00 & 12,00 & 18,00 & 24,00 \\
Bungkil Kedelai & 10,00 & 8,00 & 6,00 & 4,00 & 2,00 \\
Tepung tulang & 3,00 & 3,00 & 3,00 & 3,00 & 3,00 \\
CaCo3 & 1,00 & 1,00 & 1,00 & 1,00 & 1,00 \\
Top mix & 0,50 & 0,50 & 0,50 & 0,50 & 0,50 \\
\hline Total & 100,00 & 100,00 & 100,00 & 100,00 & 100,00 \\
\hline
\end{tabular}

\section{Pelaksanaan Penelitian}

Prosedur pembuatan produk fermentasi pertama ditimbang substrat dengan komposisi 80 limbah sawit (40\% lumpur sawit dan $40 \%$ bungkil inti sawit) dan dedak $20 \%$ dari jumlah produk fermentasi selanjutnya ditambahkan aquades sebanyak $125 \mathrm{ml} / 100 \mathrm{~g}$ substrat dan mineral brook et al sebanyak $7 \mathrm{ml} / 100 \mathrm{~g}$ subtrat. Komposisi mineral brook et al terdiri dari $\mathrm{MgSO}_{4} 7 \mathrm{H}_{2} \mathrm{O}(2,5 \mathrm{~g}), \mathrm{FeSO}_{4} 7 \mathrm{H}_{2} \mathrm{O}$ $(1 \mathrm{~g}), \mathrm{KH}_{2} \mathrm{PO}_{4}(0,01 \mathrm{~g}), \quad \mathrm{ZnSO}_{4} 4 \mathrm{H}_{2} \mathrm{O}(1 \mathrm{~g})$,
$\mathrm{MnSO}_{4} 4 \mathrm{H}_{2} \mathrm{O}(0,01 \mathrm{~g})$, Thyamin hidroklorin $(0,1225 \mathrm{~g})$ dan urea $(50 \mathrm{~g})$ dilarutkan dalam $1.000 \mathrm{ml}$ aquades. Substrat selanjutnya dikukus menggunakan autoclave dengan suhu $121^{\circ} \mathrm{C}$ selama 15 menit. Substrat yang sudah steril selanjutnya diinokulasikan jamur Pleurotus ostreatus sebanyak $8 \%$ dari jumlah subtrat, dan difermentasi selama 9 hari dengan ketebalan subtrat $2 \mathrm{~cm}$. Produk fermentasi yang telah difermentasi selanjutnya dipanen dan dijemur dibawah terik matahari sampai 
Tabel 3. Kandungan zat makanan (\%) dan energi metabolisme (kkal/kg) ransum penelitian

\begin{tabular}{lrrrrr}
\hline \multirow{2}{*}{ Zat makanan } & \multicolumn{5}{c}{ Ransum } \\
\cline { 2 - 6 } & $\mathrm{A}$ & $\mathrm{B}$ & $\mathrm{C}$ & $\mathrm{D}$ & $\mathrm{E}$ \\
\hline PK (\%) & 20,38 & 20,38 & 20,37 & 20,36 & 20,36 \\
LK (\%) & 3,60 & 3,77 & 3,93 & 4,07 & 4,26 \\
SK (\%) & 3,79 & 4,15 & 4,66 & 5,10 & 5,73 \\
Ca (\%) & 3,04 & 3,04 & 3,04 & 3,03 & 3,04 \\
P (\%) & 0,80 & 0,81 & 0,82 & 0,83 & 0,84 \\
ME (Kkal/kg) & $2.824,15$ & $2.820,44$ & $2.825,03$ & $2.842,07$ & $2.825,91$ \\
Met & 0,37 & 0,39 & 0,41 & 0,43 & 0,46 \\
Lys & 0,78 & 0,81 & 0,84 & 0,87 & 0,91 \\
\hline
\end{tabular}

Keterangan: Dihitung berdasarkan Tabel 1 dan 2

produk fermentasi tersebut kering. Produk fermentasi tesebut dicampurkan kedalam ransum sesuai dengan perlakuan.

\section{Peubah yang Diamati}

Beberapa peubah yang diamati dalam penelitian ini antara lain: konsumsi ransum (g/ekor/hari), produksi telur harian (\%), massa telur (g/ekor/ hari), dan konversi ransum.

\section{Analisa Data}

Data yang didapatkan diolah menggunakan analisis keragaman (ANOVA) sesuai dengan rancangan yang digunakan. Hasil analisa keragaman memberikan pengaruh nyata atau sangat nyata selanjutnya dilakukan uji Duncan Multiple Range Test (DMRT) guna mengetahui perbedaan antar perlakuan (Steel and Torrie, 1995).

\section{HASIL DAN PEMBAHASAN}

\section{Pengaruh Perlakuan Terhadap Performa Puyuh}

Berdasarkan Hasil analisis keragaman menunjukkan bahwa penggunaan campuran limbah sawit dan dedak yang difermentasi dengan Pleurotus ostreatus memberikan pengaruh berbeda tidak nyata $(\mathrm{P}>0,05)$ terhadap performa puyuh petelur. Konsumsi ransum puyuh petelur pada penelitian ini berkisar antara 22,55-21,51 g/ekor/hari (Tabel 4). Konsumsi ransum puyuh petelur yang sama pada perlakuan yang menggunakan
LSDF (perlakuan B, C, D, dan E) dengan perlakuan tanpa LSDF (perlakuan A) menunjukkan bahwa palatabilitas ransum yang dihasilkan sama. Hal ini menunjukkan bahwa penggunaan campuran limbah sawit dan dedak yang difermentasi dengan Pleurotus ostreatus masih disukai oleh puyuh sampai dengan penggunaan $24 \%$, walaupun pada kondisi ini terjadi pengurangan jagung sebanyak $18,94 \%$, bungkil kedelai sebanyak $80 \%$ dan pengurangan dedak sebesar $87,50 \%$ didalam ransum.

Pada penelitian ini diberikan berupa produk fermentasi yang diberikan kedalam ransum puyuh petelur. Produk fermentasi memiliki kelebihan yaitu kandungan nutrisi lebih baik dari produk asalnya. Selama proses fermentasi berlangsung terjadi proses metabolisme dan enzim dari mikroorganisme yang dapat melakukan proses oksidasi, hidrolisis, dan reaksi kimia lainnya sehingga terjadi perubahan komposisi kimiawi pada substrat sehingga kandungan nutrisi substrat lebih baik dari bahan asal (Pandey et al. 2000).

Tinggi rendahnya tingkat palatabilitas ransum sangat mempengaruhi jumlah konsumsi ransum yang akan dikonsumsi oleh ternak. Semakin tinggi tingkat palatabilitas ternak terhadap ransum yang diberikan maka akan menyebabkan semakin tingginya konsumsi ransum yang dihasilkan begitu pula sebaliknya (Adha et al., 2016). Banyak faktor yang mempengaruhi konsumsi ransum 
JPI Vol. 22 (2): 228-235

Tabel 4. Rataan performa puyuh selama penelitian

\begin{tabular}{lrrrrrr}
\hline Performa $^{\text {ns }}$ & \multicolumn{9}{c}{ Ransum perlakuan } & Standard \\
\cline { 2 - 6 } & $\mathrm{A}$ & $\mathrm{B}$ & $\mathrm{C}$ & $\mathrm{D}$ & $\mathrm{E}$ & Error \\
\hline $\begin{array}{l}\text { Konsumsi ransum } \\
\text { (g/ekor/hari) }\end{array}$ & 22,55 & 22,02 & 21,36 & 21,30 & 21,51 & 0,35 \\
Produksi telur harian (\%) & 65,08 & 64,75 & 63,42 & 62,42 & 61,08 & 2,02 \\
$\begin{array}{l}\text { Massa telur } \\
\text { (g/ekor/hari) }\end{array}$ & 6,92 & 6,96 & 6,84 & 6,68 & 6,44 & 0,23 \\
Konversi ransum & 3,26 & 3,18 & 3,14 & 3,19 & 3,34 & 0,10 \\
\hline
\end{tabular}

Keterangan: $\mathrm{ns}=$ Berpengaruh berbeda tidak nyata $(\mathrm{P}>0,05)$

selain dari palatablititas ransum itu sendiri, beberapa faktor yang akan mempengaruhi konsumsi ransum antara lain warna, bau, rasa (Mc Donald et al., 2010) serta umur dan kondisi fisiologis ternak (Akbarillah et al., 2011) selanjutnya Wahju (2004) menjelaskan konsumsi ransum dapat dipengaruhi oleh strain, umur, pakan yang diberikan, penyakit dan temperatur lingkungan. Faktor lain yang akan mempengaruhi konsumsi ransum menurut Ferket and Gernat (2006) adalah kualitas dari pakan itu sendiri antara lain komposisi nutrisi dalam ransum, kualitas pelet, dan formulasi ransum serta manajemen (manajemen lingkungan, kepadatan kandang, ketersediaan pakan dan air minum, dan kontrol terhadap bibit penyakit).

Pemberian campuran limbah sawit dan dedak fermentasi dengan Pleurotus ostreatus sampai taraf $24 \%$ didalam ransum puyuh masih bisa digunakan, hal ini dapat dilihat dengan tidak terganggunya konsumsi ransum yang dikonsumsi oleh puyuh setelah diberikan campuran limbah sawit dan dedak fermentasi dengan Pleurotus ostreatus didalam ransum. Murugesan et al. (2005) melaporkan produk fermentasi memiliki kandungan nutrisi yang lebih baik dari bahan asalnya karena mengalami perubahan yang menguntungkan seperti dihasilkan rasa yang lebih baik. Konsumsi ransum yang didapatkan pada penelitian ini sesuai dengan pendapat Marsudi dan cahyo (2012) yang menyatakan konsumsi puyuh umur antara 7- 60 minggu berkisar antara 20-22 gr/ekor/ hari.
Tidak berpengaruhnya $(\mathrm{P}>0.05)$ perlakuan terhadap produksi telur disebabkan konsumsi yang hampir sama disetiap perlakuan (Tabel 4), konsumsi yang sama menandakan jumlah zat makanan yang dikonsumsi oleh puyuh sama sehingga produksi telur harian yang dihasilkan relatif sama. Muslim et al. (2012) melaporkan produksi telur dipengaruhi oleh konsumsi ransum, meningkatnya produksi telur terjadi karena konsumsi ransum yang tinggi sehingga jumlah zat makanan yang terkandung didalam ransum yang diperlukan untuk pembentukan satu butir telur akan lebih banyak. Konsumsi ransum yang relatif sama menyebabkan konsumsi protein juga sama, pada penelitian ini konsumsi ransum tiap perlakuan antara lain perlakuan A (4,59 g/ekor/hari), perlakuan B (4,49 g/ekor/hari), perlakuan C (4,35 g/ ekor/hari), perlakuan D (4,34 g/ekor/hari), dan perlakuan E (4,38 g/ekor/hari). Protein merupakan unsur utama dalam pembentukan satu butir telur, apabila konsumsi protein tinggi maka produksi telur yang dihasilkan akan tinggi. Mousavi et al. (2013) melaporkan produktivitas yang optimal akan dipengaruhi oleh kandungan protein yang tepat didalam ransum.

Produksi telur pada perlakuan B, C, $\mathrm{D}$, dan $\mathrm{E}$ dengan perlakuan $\mathrm{A}$ yang sama dikarenakan pemberian limbah sawitdan dedak fermentasi dengan Pleurotus ostreatus dapat menutupi kandungan gizi dari jagung,bungkil kedelai dan dedak. Kelebihan dari campuran limbah sawit dan dedak fermentasi dengan Pleurotus ostreatus adalah kandungan nutrisi 
yang lebih baik dibandingkan dengan produk asal, yaitu kandungan serat kasar yang lebih rendah dan protein kasar yang lebih tinggi. Fermentasi menggunakan Pleurotus ostreatus memiliki kelebihan yaitu dapat mendegradasi lignin lebih ekstensif karena menghasilkan enzim- enzim ligninolitik antara lain laccase, lignin peroxidase dan mangan peroxidase (Periasamy and Natarajan, 2004), selain itu Pleurotus ostretaus juga menghasilkan enzim protease (Shaba and Baba, 2012), selulase dan amilase (Sudiana dan Rahmansyah, 2002). Fermentasi adalah suatu proses pengolahan pada bahan pakan yang memiliki kelebihan yaitu dapat meningkatkan kandungan protein kasar suatu bahan. Protein kasar suatu yang tinggi didapatkan dari sumbangan protein mikroba itu sendiri, hal ini sesuai dengan pendapat Boonnop et al. (2009) fermentasi memiliki kelebihan yaitu dapat meningkatkan kandungan protein kasar dari suatu bahan.

Pada penelitian ini produksi telur yang dihasilkan berkisar antara 65,08-61,08\%, hal ini sesuai dengan penelitian yang dilakukan oleh Eishu et al. (2005) yang melaporkan puyuh umur 20-32 minggu dengan pemberian protein kasar dalam ransum sebesar 20\% menghasilkan produksi telur $\pm 62,50 \%$. Hasil penelitian ini lebih rendah dari hasil penelitian yang dilakukan oleh Wuryadi (2013) bahwa puncak produksi puyuh berkisar 12-20 minggu dengan produksi telur $78-85 \%$.

Tidak berpengaruhnya $(\mathrm{P}>0.05)$ perlakuan terhadap massa telur disebabkan oleh produksi telur dan berat telur yang dihasilkan juga berpengaruh tidak nyata $(\mathrm{P}>0,05)$, pada penelitian ini didapatkan rataan berat telur berkisar antara 10,80-10,54 g/butir (Tabel 4). Hal ini sesuai dengan pendapat North and Bell (1992) bahwa massa telur erat kaitannya dengan berat telur dan produksi telur yang dihasilkan. Amrullah (2003) massa telur (g/ekor/hari) diperoleh dari rumus yaitu persentase produksi telur harian (\%) selama satu bulan dikalikan dengan berat telur (g/ butir) yang dihasilkan dalam bulan tersebut, selanjutnya Maknun et al. (2015) menyatakan bahwa produksi telur dan berat telur akan mempengaruhi massa telur yang dihasilkan. Amrullah (2003) menyatakan bahwa massa telur dibandingkan jumlah telur merupakan cara menyatakan perbandingan kemampuan produksi telur antar kelompok atau galur unggas akibat pemberian makanan dan program pengelolaan yang lebih baik. Massa telur pada penelitian ini berkisar antara 6,92$6,44 \mathrm{~g} / \mathrm{ekor} / \mathrm{hari}$.

$\begin{array}{cc}\text { Tidak berpengaruhnya } & (\mathrm{P}>0.05) \\ \text { perlakuan terhadap konversi } & \text { ransum }\end{array}$ menunjukkan bahwa penggunaan campuran limbah sawit dan dedak fermentasi dengan Pleurotus ostreatus sampai level 24\% masih ditolerir oleh puyuh, walaupun pada kondisi ini terjadi pengurangan penggunaan jagung, bungkil kedelai dan dedak didalam ransum (Tabel 4). Konversi ransum dihitung untuk mengetahui konsumsi ransum terhadap produktifitas yang dihasilkan. Setiawan (2006) menyatakan angka konversi yang rendah pada puyuh menandakan puyuh semakin efisien dalam memanfaatkan pakan yang dikonsumsi untuk produksi. Berbagai penelitian melaporkan bahwa nilai konversi ransum dapat dipengaruhi oleh kandungan nutrisi ransum, produksi telur, berat telur, bobot badan dan palatabilitas ransum (Campbell et al.,2009).

Meningkatnya konversi ransum pada perlakuan E disebabkan oleh massa telur yang menurun pada perlakuan E. Massa telur yang rendah mengakibatkan konversi ransum meningkat karena konversi ransum erat kaitannya dengan massa telur. Hal ini sesuai dengan pendapat Maknun et al. (2015) bahwa konversi ransum dipengaruhi oleh konsumsi ransum dan massa telur sehingga jika terjadi kenaikan antara keduanya maka nilai konversi ransum yang dihasilkan akan tetap seimbang. Amrullah (2003) menambahkan semakin baik kualitas ransum, maka akan semakin kecil pula nilai konversi ransumnya. Kualitas ransum yang baik ditentukan oleh keseimbangan nutrien dalam ransum itu yang diperlukan oleh ternak untuk hidup dan berproduksi. Ransum yang bermutu baik dengan kandungan gizi yang seimbang dan mempunyai palatabilitas 
yang tinggi menghasilkan konversi ransum yang semakin baik, sebaliknya ransum yang bermutu rendah dengan palatabilitas yang rendah menghasilkan konversi yang rendah.

Konversi ransum pada penelitian ini berkisar antara 3,34-3,14 (Tabel 4). Makund (2006) melaporkan bahwa konversi pakan yang baik pada puyuh adalah 3,34. Berdasarkan hasil beberapa penelitian melaporkan bahwa nilai konversi ransum dapat dipengaruhi oleh kandungan nutrien ransum, produksi telur, berat telur, bobot badan, dan palatabilitas ransum (Campbell et al. 2009).

\section{KESIMPULAN}

Pemberian campuran limbah sawit dan dedak yang difermentasi dengan Pleurotus ostreatus sampai dengan $24 \%$ didalam ransum dapat mempertahankan performa puyuh dengan konsumsi ransum 21,51 g/ekor/ hari, produksi telur harian $61,08 \%$, massa telur 6,44 g/ekor/hari, dan konversi ransum 3,34, walaupun pada kondisi ini terjadi pengurangan penggunaan jagung, bungkil kedelai dan dedak didalam ransum.

\section{DAFTAR PUSTAKA}

Adha, R. U., T. Widjastuti, dan Abun. 2016. Pengaruh penambahan tepung kunyit (Curcuma domestica Val) dalam ransum terhadap performa ayam betina sentul putih pada periode grower (816 Minggu). Universitas Padjadjaran. Bandung.

Akbarillah, T., Kususiyah, dan Hidayat. 2011. Pengaruh suplementasi tepung daun Indigofera pada tepung gaplek sebagai sumber energy pengganti jagung kuning dalam ransum puyuh (Coturnix coturnix japonica) terhadap produksi dan warna kuning telur. Jurnal Sains Peternakan Indonesia. 6(1): 33-40.

Amrullah, I. K. 2003. Nutrisi Ayam Petelur. Cetakan Pertama. Lembaga Satu
Gunung Budi. Bogor.

Boonnop, K., Wanapat, M., Nontaso, N. and Wanapat, S. 2009. Enriching nutritive value of casava root by yeast fermentation. Scientia Agricola (Piracicaba, Braz) (6): 629-633.

Campbell, J. R., Kenealy, M. D. and Campbell, K. L. 2009. Animal science: The Biology, Care, And Production Of Domestic Animals. Ed ke-4. New York (US): McGraw-Hill.

Eishu, R., Katsunori, S., Takuro, O., Tetsuo, K. and Hijedi, U. 2005. Effects of dietary protein levels on production and caracteristics of japanese quail egg. Journal of Poultry Science. 42: 130139.

Ferket, P. R. and A. G. Gernat. 2006. Factors that affect feed intake of meat birds: A Review. J. Poultry Sci. 5(10): 905-911.

Kementerian Pertanian Republik Indonesia. 2018. Statistik Pertanian 2018. Jakarta.

Maknun, L., Sri, K. dan Isna, M. 2015. Performans produksi burung puyuh (Coturnix-coturnix japonica) dengan perlakuan tepung limbah penetasan telur puyuh. Jurnal Ilmu-ilmu Peternakan. 25(3): 53-58.

Makund K. M. 2006. Response of laying japanese quail to dietary calcium levels at two levels energy. Journal of Poultry Science. 43: 351-356.

Marsudi dan Cahyo, S. 2012. Puyuh. Penebar Swadaya, Jakarta.

Mathius, I. W. 2003. Perkebunan kelapa sawit dapat menjadi basis pengembangan sapi potong. Warta Penelitian dan Pengembangan Pertanian, 25(5).

McDonald, P., Edwards, R. A., Greenhalgh, J. F. D., Morgan, C. A., Sinclair La, and Wilkinson, R. G. 2010. Animal Nutrition. Ed ke-7. New York (US): Prentice Hall.

Murugesan, G., M. Sathishkumar, and K. Swarninathan. 2005. Suplementation of waste tea fungal biomass as a 
dietary ingredient for broiler chicken. Bioresurce Technology 96: 1743-1748.

Muslim., Nuraini, dan Mirzah. 2012. Pengaruh pemberian campuran dedak dan ampas tahu fermentasi dengan Monascus purpureus terhadap performa burung puyuh. Jurnal peternakan. 9: 15-26.

Mousavi, S. N., Khalaji, S., Ghasemi-Jirdehi, A, and Foroudi, F. 2013. Investigation on the effects of dietary protein reduction with constant ratio of digestble sulfur amino acids and threonine to lysine on performance, egg quality and protein retention in two strains of laying hens. Italian Journal Animal Science. Vol. 12(2): 9-15.

Nuraini., A. Djulardi, dan A. Trisna. 2016. Peningkatan kualitas lumpur sawit dan bungkil inti sawit dengan fungi ligninolitik, selulolitik dan karatenogenik untuk memproduksi daging dan telur rendah kolesterol. Laporan Kluster Guru Besar. Lembaga Penelitian Pengabdian Masyarakat. Universitas Andalas. Padang.

Nuraini, A. Djulardi. dan D. Yuzaria. 2019. Limbah Sawit Fermentasi Untuk Unggas. Suka Bina Press. ISBN: 978623-7018-31-5.

North, M. O. and D. D. Bell. 1992. Commercial Chicken Production Manual. 4th Edition. An AVI Book Published by Van Nostrand Reinhold, New York.

Pandey, A., C. R. Soccol, and D. Mitchell. 2000. New developments in solid state fermentation: I-bioprocesses and products. Process Biochemistry. 35: 1153-1169.

Periasamy, K. and K. Natarajan. 2004. Role of lignocellulosic enzymes during basidiomata production by Pleurotus djamor var. roseas. Indian Journal of
Biotechnology. 3: 577-583.

Scott, M. L., M. C. Nesheim, and R. J. Young. 1982. Nutrition of The Chicken Fourth Ed. Published by M. L. Scott and Associates, Ithaca, New York.

Setiawan, D. 2006. Performa produksi burung puyuh (Coturnix coturnix japonica) pada perbandingan jantan dan betina yang berbeda. [Skripsi]. Fakultas Peternakan. Bogor (ID): Institut Pertanian Bogor.

Shaba, A. M. and Baba, J. 2012. Screnning of Pleurotus ostreatus and Gleophylum septarium strain for exstracelular protease enzim production. Bayero Journal of Pure and Applied Science. Vol. 5:1.

Sudiana I. M. dan Rahmansyah M, 2002. Aktivitas amilase dan selulase jamur tiram putih yang ditumbuhkan pada media ampas aren dan serbuk gergaji kayu. Jurnal Mikrobiologi Indonesia. Vol. 7: 7-10.

Steel, R. G. D. dan Torrie, J. H. 1995. Prinsip dan Prosedur Statistik. PT. Gramedia. Jakarta.

Wahju J. 2004. Ilmu Nutrisi Unggas. Yogyakarta (ID): Gajah Mada University Press.

Wuryadi, S. 2013. Beternak Puyuh. Agromedia Pustaka. Jakarta.

Yuniza, A., Y. Rizal, dan A. Sandra. 2018. Peningkatan Performa Broiler dan Kualitas Karkasnya Melalui Sistem Pemeliharaan Organik dan Pemberian Krokot (Patulaca cloracca) Sebagai Sumber Asam Lemak Omega Tiga. Laporan Akhir Penelitian Tahap I KRP2GB. PTU. Universitas Andalas, Padang. 